\title{
Otoliths of Arctic Cod (Boreogadus saida), Small Atlantic Cod (Gadus morhua), and Three Other Fish Species from Newfoundland Waters: Description and Relationship of Body Length to Otolith Length
}

\author{
Wayne W. Lidster \\ 167A Higgins Line, St. John's, Newfoundland, Canada A1B 2Y9 \\ and \\ George R. Lilly and Earl G. Dawe \\ Science Branch, Department of Fisheries and Oceans, P. O. Box 5667 \\ St. John's, Newfoundland, Canada A1C 5X1
}

\begin{abstract}
Distinguishing features of otoliths of two species of gadid fish (Arctic cod, Boreogadus saida, and Atlantic cod, Gadus morhua) are presented and include descriptions of specimens smaller than those previously described. Descriptions are also provided for otoliths of northern sand lance, Atlantic herring and capelin, three other locally and seasonally abundant fish species at Newfoundland. Regressions of body length on otolith length are presented for each of these fish species, to aid in the estimation of the sizes of prey consumed by major fish predators, such as short-finned squid, in coastal Newfoundland waters.
\end{abstract}

Key words: Arctic cod, Atlantic cod, juveniles, Newfoundland, otoliths, predation

\section{Introduction}

Sagittal otoliths of teleost fish are often found in the guts and scats of marine piscivores, and may be used to identify prey and estimate their size (Jobling and Breiby, 1986; Harkonen, 1986). During examination of stomach contents of short-finned squid (Illex illecebrosus) from coastal waters around Newfoundland, many otoliths were found which appeared to be from small gadids (Frost, 1981), but which did not clearly exhibit the characteristic features reported in descriptions and keys based primarily on otoliths from larger fish (Morrow, 1979; Frost, 1981; Harkonen, 1986). Evaluation of the possible effects of such predation on mortality of juvenile gadids will require the capability to distinguish such small otoliths. There is currently considerable interest in such studies, especially because of recent severe declines in Newfoundland cod stocks (Bishop et al., MS 1993). This paper provides descriptions and distinguishing features of otoliths of small $(<10 \mathrm{~cm})$ Atlantic cod (Gadus morhua) and Arctic cod (Boreogadus saida). We also describe features which are helpful in distinguishing these gadid otoliths from otoliths of three other species which are abundant in Newfoundland coastal waters and are commonly found in the stomachs of short-finned squid as well as various other predators (Elliot et al., 1990; Nettleship, 1991): capelin
(Mallotus villosus), herring (Clupea harengus), and northern sand lance (Ammodytes dubius). We provide, for these five species, regressions of body length on otolith length, incorporating information from juveniles smaller than those included in many previous studies.

\section{Materials and Methods}

Specimens of Atlantic cod, Arctic cod, sand lance, herring and capelin were collected with a variety of gears from inshore and offshore locations off the east coast of Newfoundland (Northwest Atlantic). Specimens of Atlantic cod were measured shortly after collection, whereas specimens of the other species were frozen and then thawed prior to measurement. The length measure used for each species was that which is commonly employed for scientific study of that species in the Newfoundland area, viz. fork length (FL, to nearest $\mathrm{mm}$ ) for Atlantic cod and Arctic cod, and total length ( $T L$, to nearest $\mathrm{mm}$ ) for the other three species. No compensation was made for possible reductions in length caused by freezing. Reductions of $1-4 \%$ have been reported for sand lance (Scott, 1973; Winters, 1981) and capelin (Bailey et al., 1977; Winters, 1982). Length of sagittal otoliths (see Appendix) was measured to the nearest $0.05 \mathrm{~mm}$, without compensation for curvature, with a vernier caliper or an ocular 
micrometer mounted in a dissecting microscope. Height was also measured for otoliths from Atlantic cod and Arctic cod. For Atlantic cod, measurements were obtained from five fish per $10 \mathrm{~mm}$ length group, whereas for the other species several nonstratified samples were combined.

The relationship between body length and otolith length was fit with least squares regressions, using linear, polynomial and power (log-log) models. Goodness of fit was judged by visual examination of residuals plotted against otolith length. When curvature was apparent in the residuals from a linear model, a quadratic term was added. Additional terms were added in a stepwise fashion if curvature persisted. Terms were retained only if their addition reduced a significant portion of the residual sum of squares. Results from power models are not reported, because residuals from power models had greater curvature than residuals from quadratic models.

The terminology used to describe otolith characteristics, taken from Harkonen (1986) and Morrow (1979), is presented in the Appendix and Fig. 1.

\section{Results and Discussion}

\section{Description of otoliths}

Atlantic cod versus Arctic cod. Harkonen (1986) has provided the most detailed comparative descriptions of fish otoliths in general, including both Atlantic cod and Arctic cod. His descriptions included some surface features of small otoliths and he presented scanning micrographs of otoliths as small as $3.84 \mathrm{~mm}$ otolith length (OL) for Atlantic cod and $2.96 \mathrm{~mm}$ (OL) for Arctic cod. Hunt (1992) included Atlantic cod otoliths as small as $4.2 \mathrm{~mm}$ (OL) in his morphometric analysis, but provided no detailed description or distinguishing characteristics. In this study we compared reference otoliths as small as $1.10 \mathrm{~mm}$ (OL) for Atlantic cod and 1.08 $\mathrm{mm}(\mathrm{OL})$ for Arctic cod (Table 1). We found that some features of relatively large gadid otoliths described by Harkonen (1986) were useful for distinguishing among smaller otoliths. Otoliths as small as about $2.5 \mathrm{~mm}$ differ in shape between species with the lateral surface clearly concave in Atlantic cod but only slightly concave in Arctic cod. Atlantic cod otoliths as small as about $2.0 \mathrm{~mm}$ display crenulation around the entire periphery (Fig. 2), whereas those of Arctic cod have only a few notches (Fig. 3). Furrows are evident on the lateral surface of Atlantic cod otoliths as small as $1.1 \mathrm{~mm}$, whereas none are evident on Arctic cod otoliths. Some crenulation may be evident in such small Atlantic cod otoliths. Curvature along the longitudinal axis was evident in Atlantic cod otoliths as small as 1.1
$\mathrm{mm}(\mathrm{OL})$, whereas Arctic cod otoliths were flat. These features alone cannot be reliably used to distinguish such small gadid otoliths.

Characteristics of the sulcus were the most reliable features for distinguishing otoliths of very small gadids. Harkonen (1986) reported that in Atlantic cod otoliths the sulcus is straight and its length exceeds $90 \%$ of the otolith length. He noted that the sulcus is slightly curved in Arctic cod otoliths and its length is only about $60 \%$ that of the otolith. The cauda is about twice the length of the ostium in Atlantic cod otoliths, whereas they are about equal in length in Arctic cod otoliths (Harkonen, 1986).

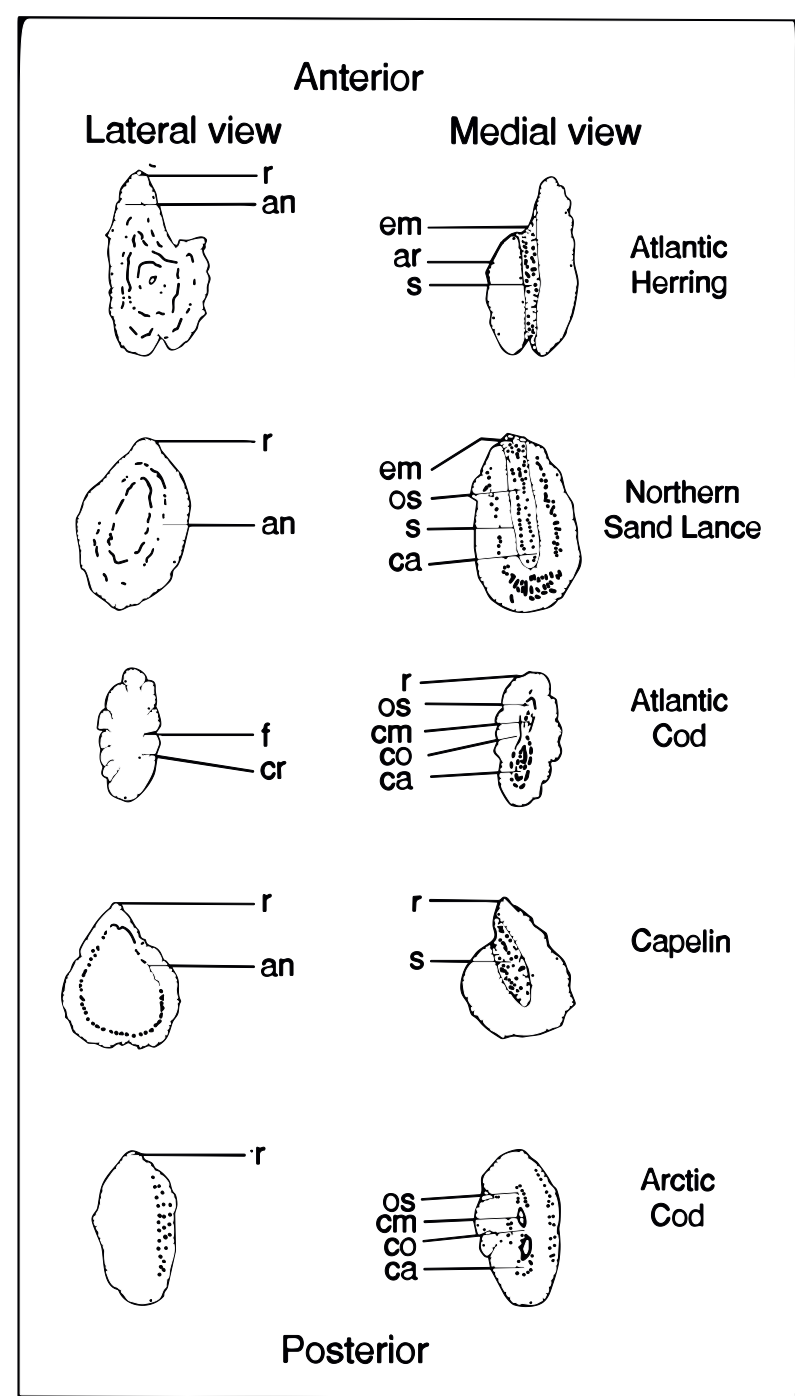

Fig. 1. Semidiagramatic drawings of sagittae of five fish species to illustrate features referred to in the text. Abbreviations for features are defined in the Appendix. 
TABLE 1. Parameter estimates of regression equations for predicting body length ( $\mathrm{BL}$, in $\mathrm{mm}$ ) from otolith length ( $\mathrm{OL}$, in $\mathrm{mm}$ ) for five species of fish. Regression equations are of the form $\mathrm{BL}=\mathrm{a}_{0}+\mathrm{a}_{1} \mathrm{OL}+\mathrm{a}_{2} \mathrm{OL}^{2}+\mathrm{a}_{3} \mathrm{OL}^{3}+\mathrm{a}_{4}$ $\mathrm{OL}^{4}$. Body length is fork length for Gadus morhua and Boreogadus saida and total length for the other species.

\begin{tabular}{|c|c|c|c|c|c|c|c|c|c|}
\hline \multirow[b]{2}{*}{ Species } & \multirow[b]{2}{*}{$a_{0}$} & \multirow[b]{2}{*}{$a_{1}$} & \multirow[b]{2}{*}{$a_{2}$} & \multirow[b]{2}{*}{$a_{3}$} & \multirow[b]{2}{*}{$a_{4}$} & \multirow[b]{2}{*}{$r^{2}$} & \multirow[b]{2}{*}{$\mathrm{N}$} & \multicolumn{2}{|c|}{ Otolith length $(\mathrm{mm})$} \\
\hline & & & & & & & & Min. & Max. \\
\hline Gadus morhua & $\begin{array}{r}-15.003 \\
25.751\end{array}$ & $\begin{array}{l}25.546 \\
10.109\end{array}$ & 1.165 & & & $\begin{array}{l}0.965 \\
0.980\end{array}$ & 227 & 1.10 & 12.05 \\
\hline Boreogadus saida & $\begin{array}{r}6.088 \\
19.433\end{array}$ & $\begin{array}{l}24.711 \\
18.612\end{array}$ & 0.546 & & & $\begin{array}{l}0.980 \\
0.984\end{array}$ & 270 & 1.08 & 11.55 \\
\hline Ammodytes dubius & -13.547 & 76.454 & & & & 0.923 & 486 & 1.04 & 3.07 \\
\hline Clupea harengus & 15.627 & 57.860 & & & & 0.982 & 477 & 0.87 & 3.02 \\
\hline Mallotus villosus & $\begin{array}{r}11.726 \\
-23.151\end{array}$ & $\begin{array}{r}56.221 \\
215.741\end{array}$ & -176.657 & 71.062 & -9.449 & $\begin{array}{l}0.958 \\
0.976\end{array}$ & 407 & 0.64 & 3.42 \\
\hline
\end{tabular}

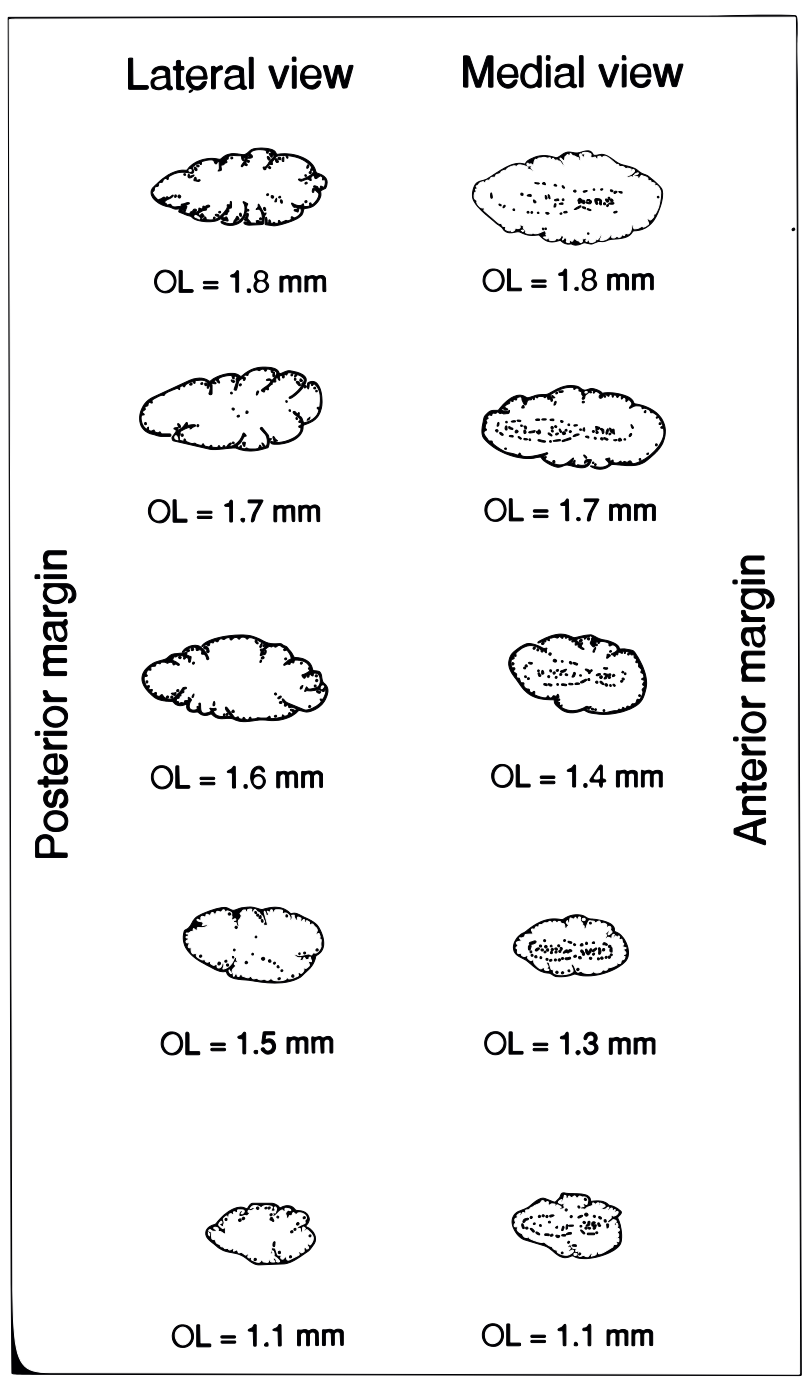

Fig. 2. Variation in structure of Atlantic cod otoliths with otolith length (OL).

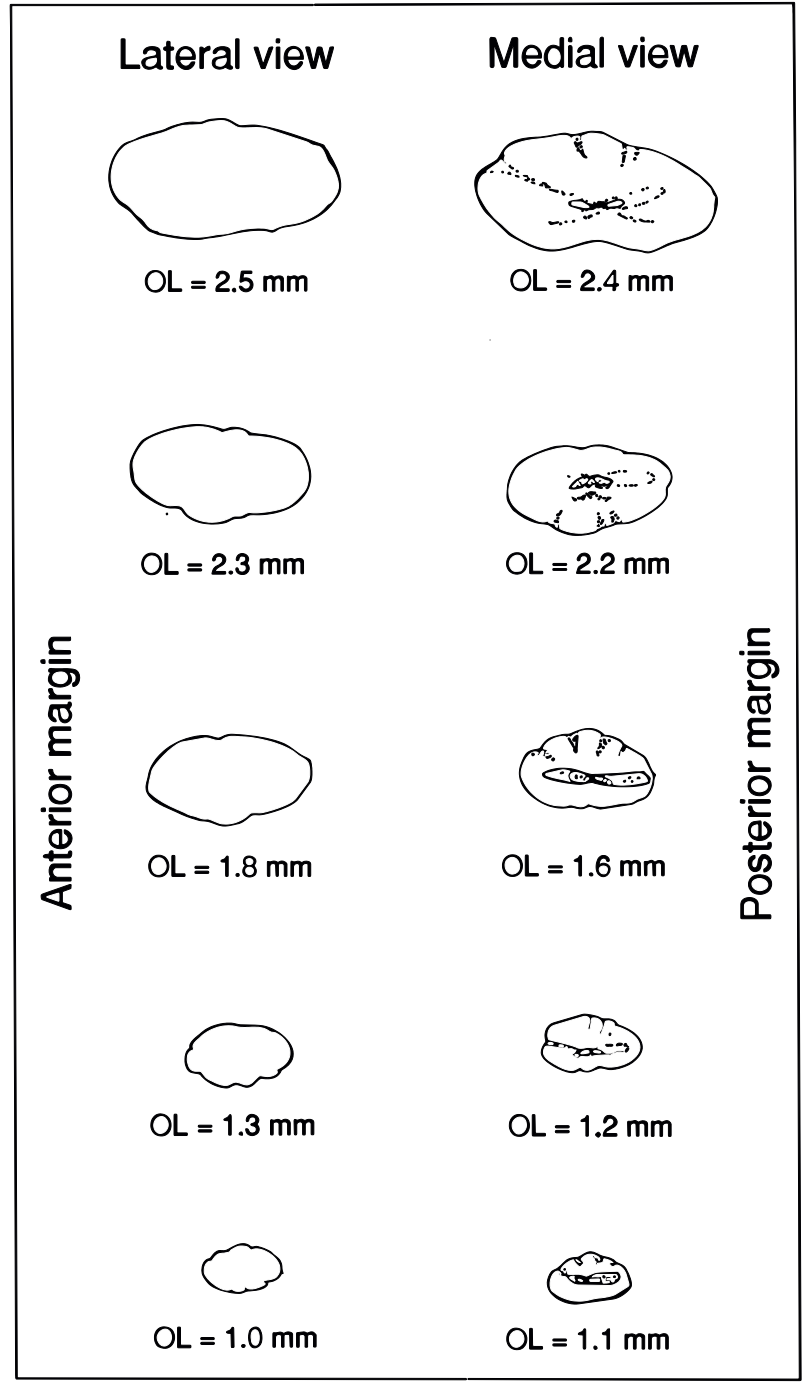

Fig. 3. Variation in structure of Arctic cod otoliths with otolith length $(\mathrm{OL})$. 
We found in the smallest otoliths within our reference collection that those of Atlantic cod $(1.1 \mathrm{~mm}$ OL, Fig. 2) displayed a well-developed sulcus which extended about $90 \%$ of the total otolith length. Cristae (especially the crista inferior) were well developed and the cauda was clearly longer than the ostium. Our smallest Arctic cod otoliths (1.1 mm OL, Fig. 3) possessed a poorly-defined sulcus. The otolith medial surface was thickened about the entire periphery and the sulcus was a shallow depression. Cristae were not sufficiently well developed to identify the collum or distinguish between the cauda and ostium.

Within each of these gadid species, individual variability in shape and surface features of small otoliths is considerable. It is necessary to manipulate small otoliths to make best use of reflected light when examining the sulcus. Although comparison of reference gadid otoliths was possible only to a minimum size of $1.1 \mathrm{~mm}(\mathrm{OL})$ (Table 1), we could recognize distinguishing features in smaller otoliths which were recovered from squid stomachs. We found that characteristics of the sulcus could be used to consistently identify gadid otoliths as small as $0.5 \mathrm{~mm} \mathrm{OL}$ and, in many cases, otoliths as small as $0.27 \mathrm{~mm}$ OL could be distinguished. Comparison to known otoliths is recommended, if possible, before attempting to identify such small gadid otoliths.

Frost (1981) found the height to length ratio to be helpful in distinguishing between Arctic cod and Pacific cod (Gadus macrocephalus). She reported that the ratio was usually greater than 0.44 in $\mathrm{Pa}-$ cific cod and usually less than 0.47 in Arctic cod, although in Arctic cod otoliths shorter than $4.0 \mathrm{~mm}$, the ratio was sometimes greater than 0.5 . We found that the ratio would be a useful distinguishing character for Arctic cod and Atlantic cod only in relatively large otoliths; an otolith longer than $8 \mathrm{~mm}$ with a ratio greater than 0.40 would likely be from an Atlantic cod, and any otolith with a ratio less than 0.38 would likely be from an Arctic cod (Fig. 4).

Other species. Gadid otoliths are easily distinguished from those of the three other fish species which are considered here. Otoliths of those other species have a well developed rostrum and at least one excisura, whereas otoliths of the two gadids display neither.

Northern sand lance (Ammodytes dubius) otoliths as small as $0.35 \mathrm{~mm}$ OL have been described in detail by Scott (1973). His description accurately represents our Ammodytes spp. otoliths. These otoliths are irregularly almond-shaped, due to otolith growth at the anterior end (Fig. 1). A rostrum forms as an extension of the central anterior margin. A sulcus develops as a slight groove on the medial surface, in otoliths larger than about 1.0 $\mathrm{mm} \mathrm{OL}$. The very shallow sulcus is variable in length but it does not exceed $70 \%$ of the otolith length. The cauda and ostium are not easily distinguished. The ostium is open, usually with a broad excisura major, sometimes located at the tip of the rostrum (Breiby, 1985). Otolith margins are smoothly rounded but somewhat irregular.

Atlantic herring (Clupea harengus) otoliths as small as $0.31 \mathrm{~mm}$ OL were described by Harkonen (1986). These otoliths are discoid in post larvae but adopt the shape of those from adults at about 1.0 mm OL (Morrow, 1979; Harkonen, 1986; Fig. 1). A prominent rostrum which is rounded at the tip and an antirostrum are evident in such larger otoliths. Otolith height does not exceed $55 \%$ of its length. The sulcus is wide, open at both ends and not divided between a cauda and ostium. Its posterior (or caudal) end is narrow and very shallow, whereas its anterior end is broader and deeper, opening close to the tip of the rostrum. The notch of the excisura major is deep and narrow, forming an angle of much less than $90^{\circ}$ (Morrow, 1979). In most otoliths larger than about $2.0 \mathrm{~mm} \mathrm{OL}$, the posterior margin is bilobed and the lateral surface concave.

Capelin (Mallotus villosus) otoliths have been previously described, but based on a minimum size of $1.80 \mathrm{~mm}$ OL (Harkonen, 1986); considerably larger than the smallest within our reference collection (0.65 mm OL, Table 1). Capelin otoliths (Fig. 1) also take on adult features during post-larval to juvenile stages (Harkonen, 1986; Morrow, 1979). The rostrum is prominent, usually one-third the otolith length, and is pointed at the tip. The

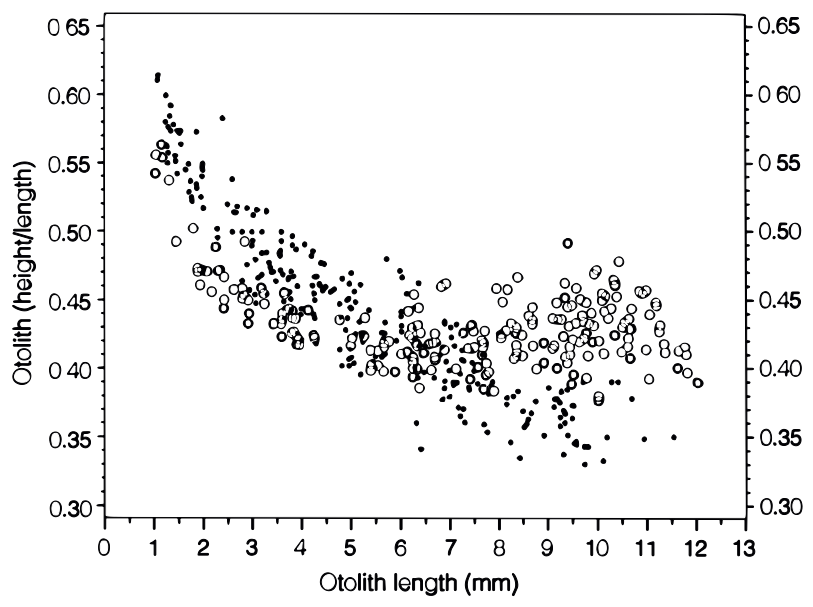

Fig. 4. Relationship of the otolith height/length ratio to otolith length, for Atlantic cod (open circles) and Arctic cod (closed circles). 
antirostrum is not as well developed as in herring otoliths and it may not be visible in otoliths smaller than about $1.6 \mathrm{~mm}$ OL. Otoliths are robust, with otolith height exceeding $55 \%$ of otolith length (Morrow, 1979). The sulcus is shallow and often the cauda and ostium cannot be distinguished. Both Morrow (1979) and Breiby (1985) reported that the sulcus is open at both ends. However, we agree with Harkonen (1986) that it is usually closed at the posterior (caudal) end. The excisura major does not extend to the tip of the rostrum and the excisural notch is not as deep as it is in herring otoliths.

\section{Body length - otolith length relationships}

For three of the species, there was no consistent difference in length between left and right otoliths (paired t-test: Atlantic cod, $\mathrm{t}=0.54$, $\mathrm{df}=$ 94, $\mathrm{P}>0.05$; Arctic cod, $\mathrm{t}=0.47, \mathrm{df}=160, \mathrm{P}>$ 0.05 ; capelin, $t=-1.154$, $d f=188, P>0.05)$. A difference was found in the other two species (sand lance, $\mathrm{t}=-3.25, \mathrm{df}=237, \mathrm{P}<0.01$; herring, $\mathrm{t}=$ $2.44, d f=206, P<0.05)$, but in both cases the mean difference $(0.007 \mathrm{~mm}$ and $0.008 \mathrm{~mm}$ for sand lance and herring, respectively) was less than the precision of measurement $(0.05 \mathrm{~mm})$. We concluded that right and left otoliths could be combined in equations predicting body length.

Linear regressions of body length on otolith length provided good fits to the data for all species (Table 1, Fig. 5-9), but examination of plots of residuals versus otolith length revealed departures from linearity. Other investigators have modelled such non-linear relationships with power curves or polynomials (Quinn et al., 1983; Harkonen, 1986; Hunt, 1992), fitted two or more straight lines

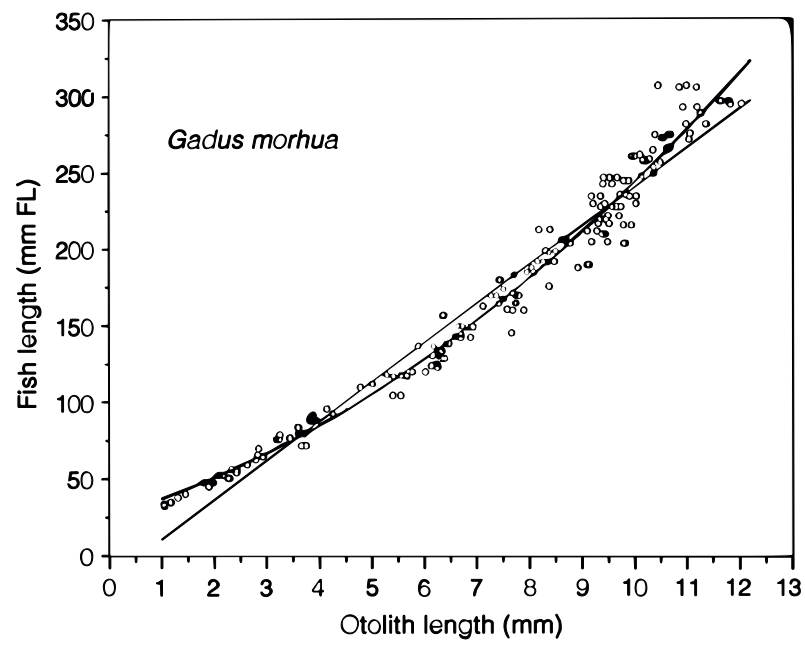

Fig. 5. Application of both linear and quadratic (heavy line) regression models to the data on body length versus otolith length for Atlantic cod.

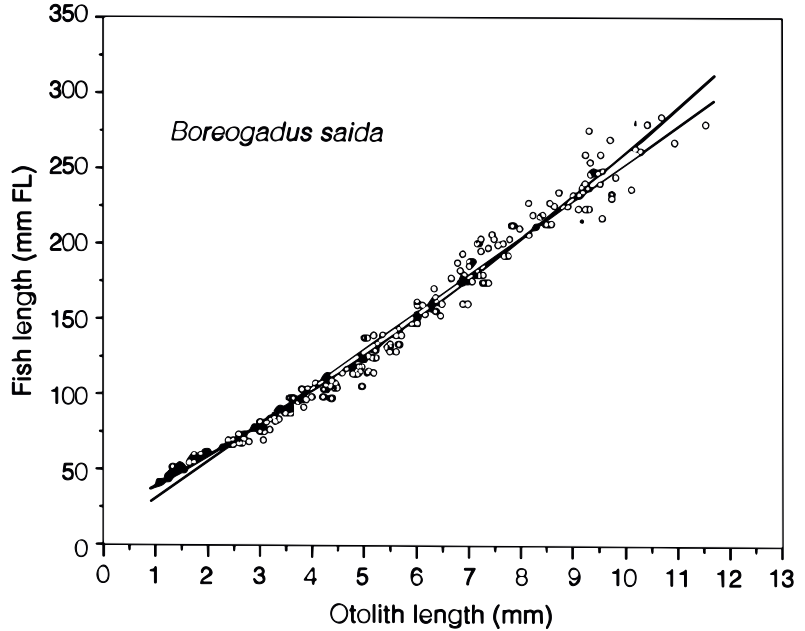

Fig. 6. Application of both linear and quadratic (heavy line) regression models to the data on body length versus otolith length for Arctic cod.

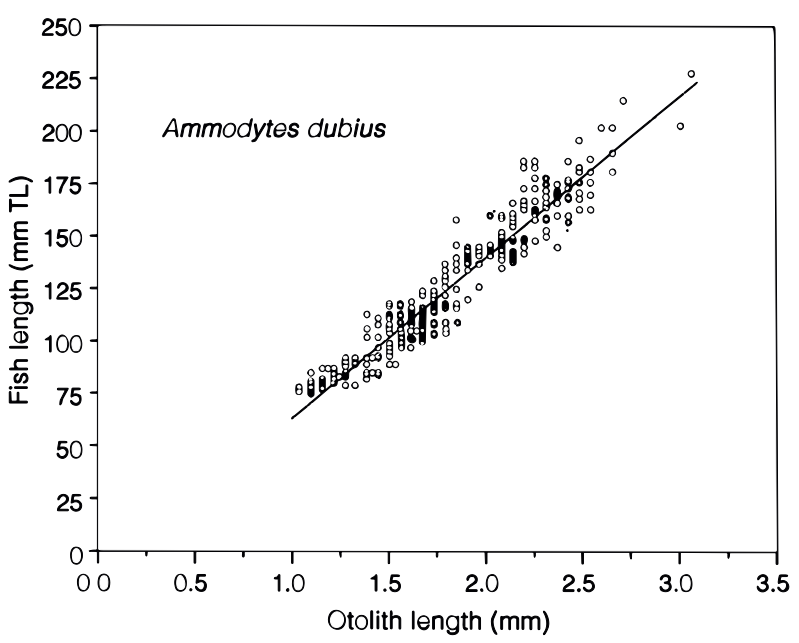

Fig. 7. Application of a linear regression model to the data on body length versus otolith length for northern sand lance.

(Templemen, 1968; Frost and Lowry, 1981; Winters, 1981), or drawn a line by eye (Scott, 1973; Bailey et al., 1977; Winters, 1982). We found that no single model was most appropriate for all species. While a simple linear regression was adequate over a wide size range for sand lance and herring, an improved fit was provided for Atlantic cod and Arctic cod by a quadratic model and for capelin by a fourth order polynomial (Table 1, Fig. 5-9).

It is not clear what influences the number and magnitude of inflexions in the relationship between 


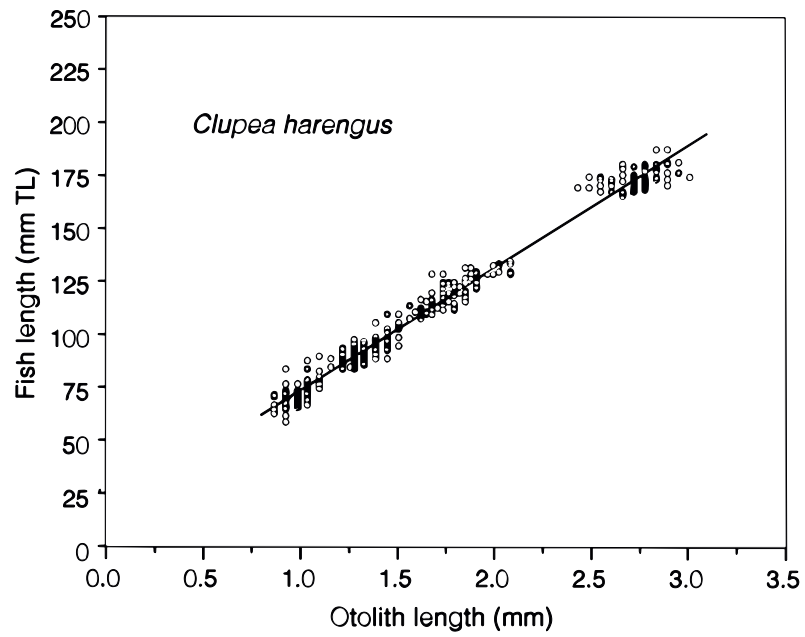

Fig. 8. Application of a linear regression model to the data on body length versus otolith length for herring.

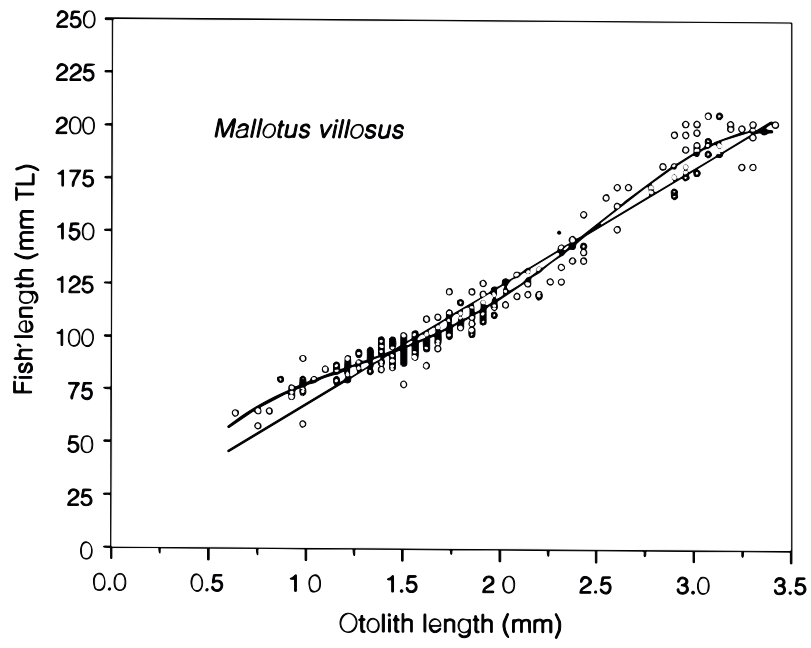

Fig. 9. Application of both linear and polynomial regression models to the data on body length versus otolith lenath for cabelin.

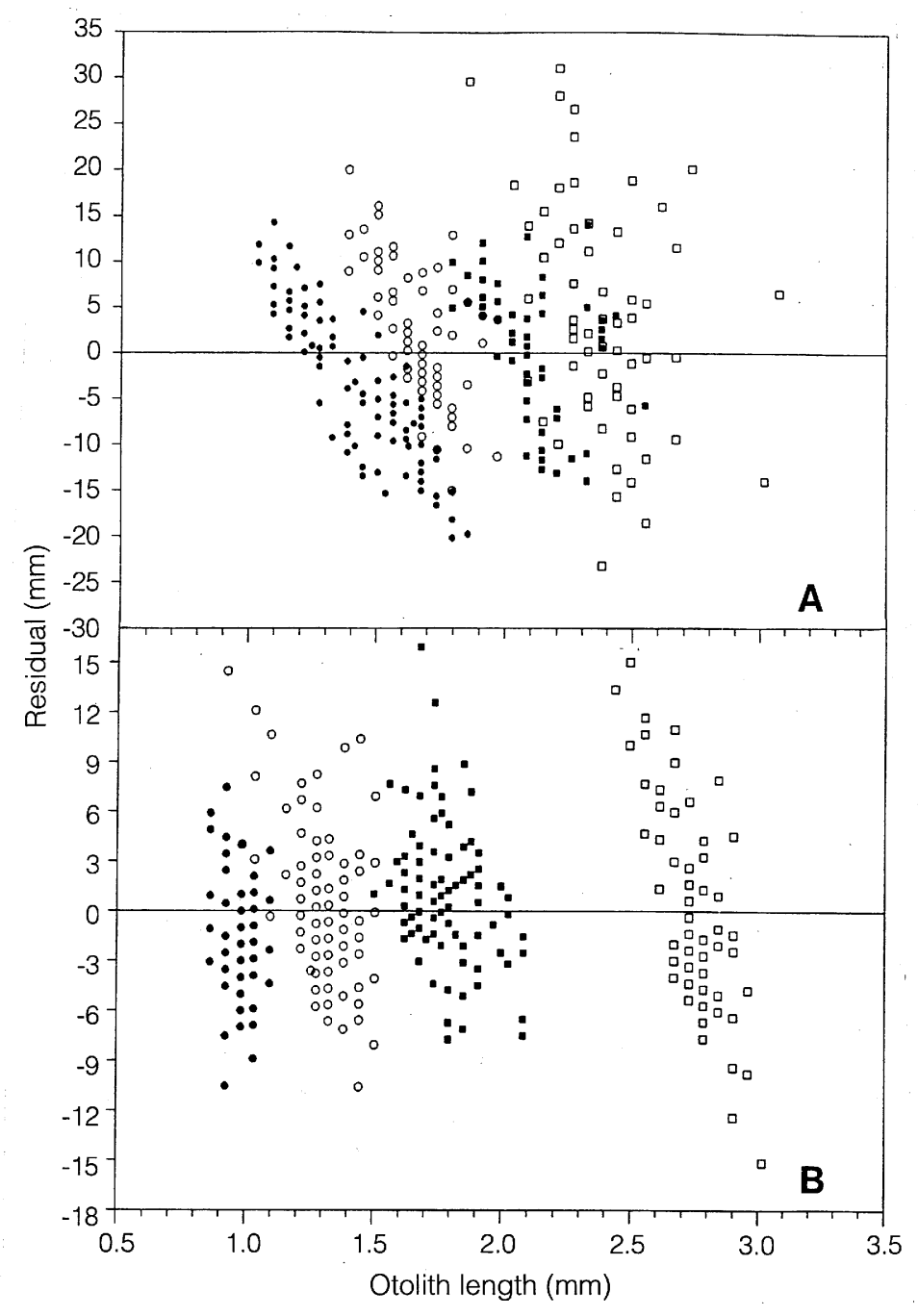

Fig. 10. Residuals from a linear regression of body length on otolith length for (A) sand lance and (B) herring. Different symbols represent different samples. 
body length and otolith length. In some species, such as Atlantic cod and Arctic cod, there may be a single dominant curvature which may be modelled with a quadratic or a power curve. However, in other species, such as capelin, there appear to be several points of inflexion, one of which may be associated with the attainment of maturity (Templeman, 1968; Winters, 1982). We note that, in some species, plots of residuals from linear regressions reveal an effect of sample time, sample location, or modal group (Fig. 10). The combining of several samples might give the appearance of several inflexions, and the number of terms required to fit such data might vary with the number of samples and their distinctness.

Further investigation of the phenomenon illustrated in Fig. 10 is beyond the scope of this paper, but we feel it may be of considerable importance. It is possible, for example, that the slope of a regression calculated for an individual cohort sampled at a specific time and place may be lower than the slope calculated from combined samples of several cohorts, or the same cohort sampled several times over its life time. If this is the case, then use of a regression calculated from several samples combined might yield underestimates of the body length of small fish in a specific cohort, and overestimates of the large fish in that cohort. The difference could be as much as 15-25 mm (Fig. 10). This possibility could be tested by obtaining samples of cohorts of different ages, and comparing within-sample regressions with a regression calculated from combined samples.

\section{Acknowledgements}

Our sincere thanks are extended to those who provided reference otoliths for this study; David Methven (Ocean Sciences Center, Memorial University of Newfoundland), and numerous individuals in Science Branch (Department of Fisheries and Oceans, St. John's, Newfoundland), especially David McKinnon, Norman Batten and Philip Eustace. Comments and criticisms offered by Edgar Dalley and two anonymous reviewers were appreciated.

\section{References}

BAILEY, R. F. J., K. W. ABLE, and W. C. LEGGETT. 1977. Evidence for the presence of a metamorphic check in capelin (Mallotus villosus) otoliths and implications for age determination. J. Fish. Res. Board Can., 34: 2008-2014.

BISHOP, C. A., E. F. MURPHY, M. B. DAVIS, J. W. BAIRD, and G. A. ROSE. MS 1993. Assessment of the cod stock in NAFO Divisions $2 \mathrm{~J}+3 \mathrm{KL}$. NAFO SCR Doc., No. 93, Serial No. N2271, $51 \mathrm{p}$.

BREIBY, A. 1985. Otoliths from marine fishes in North Norway. Tromura, Naturvitenskap, No. 45: 1-31.

ELLIOT, R. D., P. C. RYAN, and W. W. LIDSTER. 1990. The winter diet of thick-billed murres in coastal Newfoundland waters. Stud. Avian Biol., 14: 125-138.

FROST, K. J. 1981. Descriptive key to the otoliths of gadoid fishes of the Bering, Chukchi and Beaufort Seas. Arctic, 34(1): 55-59.

FROST, K. J., and L. F. LOWRY. 1981. Trophic importance of some marine gadoids in Northern Alaska and their body-otolith size relationships. Fish. Bull. U.S., 79(1): 187-192.

HARKONEN, T. 1986. Guide to the otoliths of the bony fishes of the Northeast Atlantic. Danbiu ApS. Biological Consultants. Henningsens Allé 58, DK-2900, Hellerup, Denmark, 256 p.

HUNT, J. J. 1992. Morphological characteristics of otoliths for selected fish in the Northwest Atlantic. J. Northw. Atl. Fish. Sci., 13: 63-75.

JOBLING, M., and A. BREIBY. 1986. The use and abuse of fish otoliths in studies of feeding habits of marine Piscivores. Sarsia, 71: 265-274.

MORROW, J. E. 1979. Preliminary keys to otoliths of some adult fishes of the Gulf of Alaska, Bering Sea, and Beaufort Sea. NOAA Tech. Rep., NMFS CIRC-420, $32 \mathrm{p}$.

NETTLESHIP, D. N. 1991. The diet of Atlantic Puffin chicks in Newfoundland before and after the initiation of an international capelin fishery, 1967-84. Acta XX Cong. Internat. Ornithol., p. 2263-2271.

QUINN, T. J., E. A. BEST, L. BIJSTERVELD, and I. R. McGREGOR. 1983. Sampling Pacific halibut (Hippoglossus stenolepis) landings for age composition: history, evaluation, and estimation. Sci. Rep. IPHC, No. 68.

SCOTT, J. S. 1973. Otolith structure and growth in northern sand lance, Ammodytes dubius, from the Scotian Shelf. ICNAF Res. Bull., 10: 107-115.

TEMPLEMAN, W. 1968. Review of some aspects of capelin biology in the Canadian area of the Northwest Atlantic. ICES Rapp. Proc.-Verb., 158: 41-53.

WINTERS, G. H. 1981. Growth patterns in sand lance, Ammodytes dubius, from the Grand Bank. Can. J. Fish. Aquat. Sci., 38: 841-846.

1982. Life history and geographical patterns of growth in capelin, Mallotus villosus, of the Labrador and Newfoundland areas. J. Northw. Atl. Fish. Sci., 3: 105-114. 


\section{Appendix}

Terminology used to describe otolith characteristics (adapted from Morrow, 1979).

\begin{tabular}{|c|c|c|}
\hline annuli (an) & - & $\begin{array}{l}\text { the light (hyaline) and dark (opaque) rings visible in otoliths which indicate calcium de- } \\
\text { posit over a one-year period. }\end{array}$ \\
\hline antirostrum (ar) & - & $\begin{array}{l}\text { the anterio-dorsal margin of an otolith, dorsal to the notch of the excisura major (usually } \\
\text { much smaller than the rostrum). }\end{array}$ \\
\hline cauda (ca) & - & the posterior portion of the sulcus, posterior to the collum. \\
\hline colliculum $(\mathrm{cm})$ & - & $\begin{array}{l}\text { the raised portion of the floor of the sulcus. May exist in the ostium, the cauda, neither or } \\
\text { both. }\end{array}$ \\
\hline collum (co) & - & a constriction of the sulcus, usually located near the middle of the sulcus. \\
\hline crenulation (cr) & - & notches around the ventral and dorsal margins of an otolith. \\
\hline crista & - & $\begin{array}{l}\text { refers to the rim around the sulcus. If dorsal, it is called crista superior (cs). If ventral, it is } \\
\text { called crista inferior (ci). }\end{array}$ \\
\hline excisura (e) & - & $\begin{array}{l}\text { the opening of the sulcus at the margin of an otolith. The anterior opening is the excisura } \\
\text { major (em). The posterior opening is the excisura minor (emi). If the sulcus does not } \\
\text { reach the margin there is no excisura. }\end{array}$ \\
\hline furrows (f) & - & wrinkle-like grooves on the lateral surface of some otoliths. \\
\hline height of otolith $(\mathrm{OH})$ & - & the greatest straight line distance from the dorsal to the ventral margin of an otolith. \\
\hline length of otolith $(\mathrm{OL})$ & - & the greatest straight line distance from the posterior to the anterior margin of an otolith. \\
\hline ostium (os) & - & the anterior portion of the sulcus, anterior to the collum. \\
\hline rostrum (r) & - & the anterior extension of the ventral portion. \\
\hline sulcus (s) & - & the longitudinal groove on the medial surface of the otolith. \\
\hline
\end{tabular}

